\title{
Composition of the diet of the Iberian common toad (Bufo spinosus, Daudin, 1803) in central Spain
}

\author{
Álvaro Vallvé1, Iván Sánchez-Iglesias2,* \\ ${ }^{1}$ Universidad Autónoma de Madrid, Calle Ramonet, 44, 28033 Madrid, Spain. \\ 2 Universidad Complutense de Madrid, Departamento de Psicobiología y Metodología de las Ciencias del \\ Comportamiento, Campus de Somosaguas, 28223 Pozuelo de Alarcón, Madrid, Spain. \\ *Correspondence: Phone: +34 620384693, E-mail: i.sanchez@psi.ucm.es
}

Received: 31 December 2017; returned for review: 28 February 2018; accepted: 29 November 2018.

We describe the diet of the Iberian common toad (Bufo spinosus) in a locality in central Spain. The sample consisted of individuals that were road-killed in road M-301 between Madrid and San Martín de la Vega during their seasonal migration events in spring and fall. The diet of B. spinosus comprises up to 42 different taxonomic families of invertebrates, of which Julidae, Carabidae, Staphylinidae, and Formicidae were the most abundant. When considering the biomass of these prey, the results were consistent except for Formicidae, whose importance is limited $(2.63 \%$ of the total biomass). Biomass estimations for Julidae were compared to empirically obtained data, which showed a high content of inorganic matter (41.4\%) in these invertebrates. Nevertheless, Julidae is still the leading contributor in consumed biomass in our samples (42\%). We highlight the occurrence of supposedly unpalatable (Lampyridae) and nutritionally poor items (vegetal matter and fecal pellets of lagomorphs).

Key words: central Iberian Peninsula; diet; Formicidae; Julidae; seasonal migrations; trophic spectrum.

The Iberian common toad (Bufo spinosus, Daudin, 1803) was formerly considered a local variation of the common toad Bufo bufo (L. 1758) with subspecific rank, but has been recently recognized as a distinct species (e.g. Arntzen et al., 2013). Gathering new data specifically pertaining to this species is therefore of interest to better characterize its general biology. Here we provide new data on the trophic ecology of the species, which has been previously investigated in several studies, most of which were based on small sample sizes (BAs, 1982; Lizana et al., 1986; LizAnA, 1990; BeA et al., 1994; CAMPeny \& Montori,
1995; Vignes, 1998; Díaz-Paniagua et al., 2005).

In this paper we describe the trophic spectrum of B. spinosus in central Spain based on a large sample (91 individuals) from a population inhabiting a Mediterranean agricultural landscape in "Parque Regional del Sureste", a protected area south of the city of Madrid. The studied population has been monitored for years due to the high impact of road mortality during the seasonal migrations of the toads: 1319, 1139, 1560 and 594 dead adult toads were counted in road surveys during the years 2008, 2009, 2010 and 2011, 
respectively (E. Ayllón, personal communication; see also PAÑos et al., 2009). These figures are amongst the highest reported in the scientific literature (e.g. GitTins et al., 1980; SAntos et al. 2007; GLista et al., 2008; Schmidt \& Zumbach, 2008; Kovar et al., 2009). During these mass mortality events, dead toads were collected in order to conduct studies on their biometry and characterize the genetic diversity (TRujILlo et al., 2017), demography (by skeletochronological analyses), and trophic ecology of the population, which is the main focus of the present study.

\section{Materials and Methods}

\section{Study area}

The studied population of the Iberian common toad (B. spinosus) is located about $30 \mathrm{~km}$ south of the city of Madrid, near the town of San Martín de la Vega. The population breeds in an abandoned water reservoir (Embalse de Gózquez. UTM coordinates: Time zone 30T, $\mathrm{x}=$ 450960, y = 4454368, datum WGS84, Fig. 1) located within the boundaries of "Parque Regional del Sureste". Terrestrial and breeding habitats are separated by road $\mathrm{M}$ -301, which connects Madrid and San Martín de la Vega. The high traffic density causes a high mortality of individuals during the toads" seasonal migration events in rainy nights in the spring and fall, especially on a section spanning $3.6 \mathrm{~km}$ from "La Marañosa" military base to the roundabout of Gózquez de Arriba (Fig. 1), where all samples for this study were collected. This section runs mostly from north to south, slightly sloping southwards. Geographically, the studied area is in the center of the Iberian Peninsula, included in the temperate Mediterranean climatic domain, with a continental Mediterranean climate. Mean annual precipitation in the study area is $434 \mathrm{~mm}$ and the mean daily temperature is $14^{\circ} \mathrm{C}$ (highest daily mean temperature $24.8^{\circ} \mathrm{C}$; lowest daily mean temperature $5.5^{\circ} \mathrm{C}$ ).

The terrestrial habitat consists of pine plantations (Pinus nigra, Arnold, 1785) with patches of dryland agricultural fields in the west, whereas in the east of the study area, gypsicolous scrublands and kermes oak groves predominate, accompanied by dryland agriculture areas $>50 \%$ dryland, $<25 \%$ olive grove, $>25 \%$ noncultivated), as well as irrigation fed crops.

\section{Sampling and taxonomic identification}

The collected samples were dead (runover) individuals of $B$. spinosus found along the M-301 road during the years 2010 (October, N = 69) and 2011 (March, N $=18$, and October, $\mathrm{N}=13$ ). Only 91 specimens with intact stomachs were studied, and only the content in the stomachs was considered, leaving out any prey remains located elsewhere in the digestive tract. The collected carcasses with the associated biometric data were deposited in the tissue and DNA collection at Museo Nacional de Ciencias Naturales (MNCN-CSIC) in Madrid, to foster further studies on this population.

The taxonomic identification of the prey recovered from the stomachs was made visually with a Leica MZ12 binocular magnifying glass, and with the use of general and specific entomology guides (Gómez-Menor, 1956; Harde \& Severa, 1984; Jones, 1985; Martínez et al., 1985; Alonso-Zarazaga \& Mansilla Castrillo, 


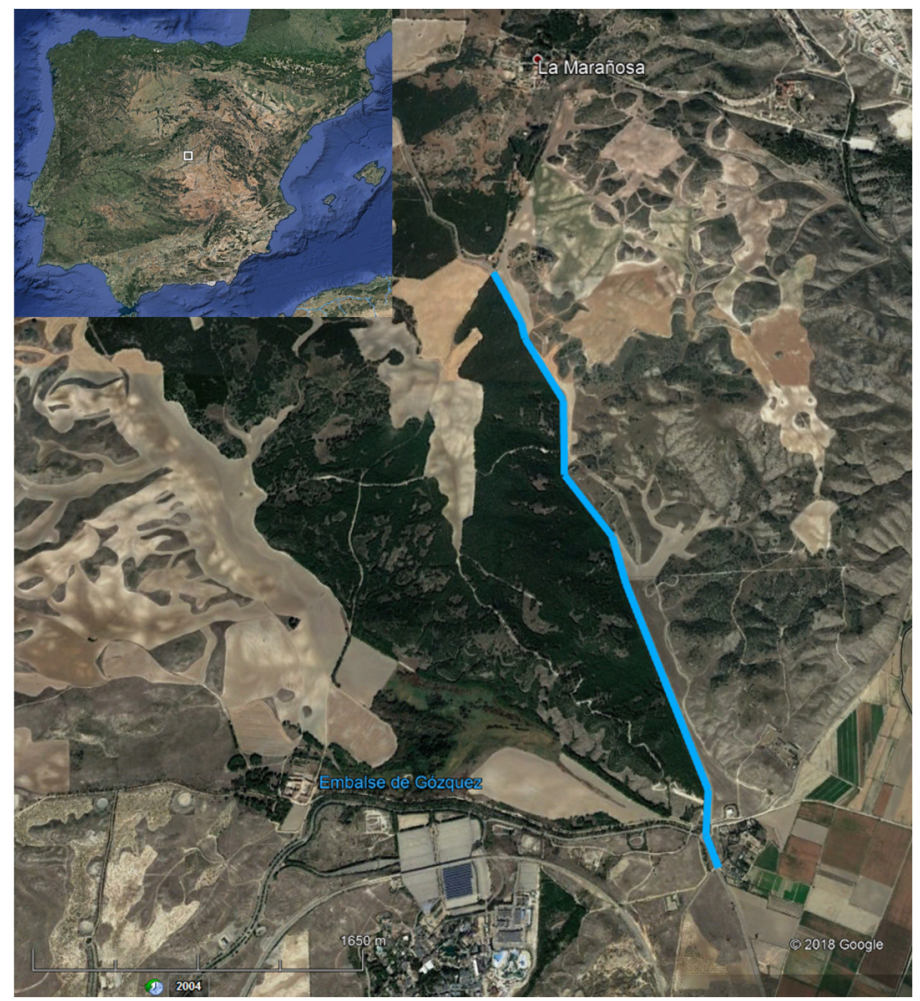

Figure 1: Study area along the M-301 road north of the town of San Martín de la Vega (Madrid), with indication of its approximate location in the Iberian Peninsula (white square in the top map) central Spain, and of Embalse de Gózquez, the water reservoir where the $B u f o$ spinosus population breeds. Image downloaded and modified from Google Earth, and published according to the guidelines established by the copyright owner; see Google Permissions at http://www.google.com/ permissions/geoguidelines.html.

1988; Chinery, 1988; ZahradniK, 1990; ORtuño Hernández \& Toribio, 1996). We identified the prey to family level whenever possible, and counting was made upon the most repeated segment or appendix (most prey remains were anatomically disarticulated).

Antero-posterior length of the prey was measured with a hand caliper $( \pm 0.1 \mathrm{~mm}$, although values were rounded to the first decimal place). The biomass of the ingested prey was estimated by using the generic formula $B=a \cdot L^{b}$, where $B$ is the estimated biomass in milligrams, $L$ is the antero-posterior length in millimeters, and $a$ and $b$ are specific constant values obtained from HódAR (1996) for the same or similar invertebrate families. Because our sample contained some invertebrate families that were not studied by this author, in these cases the constant values of other, similar invertebrates were used: "Coleoptera larvae" and "Diptera Muscidae larvae" were calculated using "Carabidae larvae"; "Diptera Tipulidae larvae" were treated as "Lepidoptera larvae"; all "Heteroptera Hemiptera" were calculated using the generic constant values for "Heteroptera"; and "Coleoptera Malachiidae", "Coleoptera Lagriidae", "Coleoptera Buprestidae" and all non-identified coleopterans were treated as "Coleoptera unidentified" (Hódar, 1996). Exceptionally, for earthworms (Oligochaeta) and the single snail (Gastropoda) found in our sample, the biomass was empirically calculated by means of dry weight measurement on a precision scale (Denver Instruments 
APX-200) to the nearest $0.0001 \mathrm{~g}$, after drying at $60^{\circ} \mathrm{C}$ in an electric stove until constant weight was reached (QuINNEY \& ANKNEY, 1985). For earthworm (Oligochaeta) biomass estimations, the generic formula of a cylinder was used: $B$ $=a \cdot L^{3}$ (Margalef, 1983), where $B$ is the biomass in grams, $L$ the antero-posterior length in millimeters, and $a$ the empirically obtained constant value $\left(a=1.03778^{-07}\right.$, $\mathrm{N}=3$ ). Furthermore, the dry weight of a subsample of Julidae millipedes was also measured following the same procedure (dry weight constant value $a=2.06233^{-06}, \mathrm{~N}$ =23), and their ash-free inorganic weight was obtained (inorganic weight constant value $a=8.53722^{-07}, \mathrm{~N}=12$ ) through burning at $450^{\circ} \mathrm{C}$ in an electric muffle (Carbolite ELF $11 / 61100^{\circ} \mathrm{C}$ ).

\section{Data analysis and variables}

The listed invertebrate taxa (at the family level) include all prey items that appeared in our sample, which were classified into 48 different groups that do not necessarily reflect phylogenetic divisions. For example, larvae of different coleopterans were listed separately from the adults. This was done for two reasons: first, to be able to calculate the biomass of the specimens, since larvae and adult coleopterans require different calculations. Second, because larvae and adults of many invertebrates belong to different ecological niches, have different behaviors and therefore can be subject to differential predation by $B$. spinosus. This study does not discuss the feeding behavior of $B$. spinosus due to insufficient data, but we still list the groups separately with the hope that they will be useful for future studies in this regard.
For each invertebrate group we studied three different variables: N\% represents the percentage that each invertebrate group contributes to the total amount of sampled prey; this gives an idea of the numeric importance of each group in the diet of the B. spinosus. B\% represents the percentage that each invertebrate group contributes to the total prey biomass; this variable is important to understand $B$. spinosus diet because very abundant prey like ants (Formicidae) could nevertheless contribute little in total biomass, whilst scarcer but bigger prey may have a higher relative significance in the toad diet. Finally, F\% is the frequency of an invertebrate group that has appeared at least once in the stomach of a toad in our samples, representing how often different individuals prey on certain taxonomic groups.

\section{Results}

Based on a sample of 1158 prey items from 91 toads, our results show that the diet of B. spinosus in the study area is very diverse, comprising at least 42 different invertebrate families (Table 1). Many of these groups contribute little in number of individuals or in biomass to the diet of the toads, for instance spiders (Araneae) or snails (Mollusca Gastropoda), but are nevertheless noteworthy because they show the taxonomic breadth of the diet of B. spinosus.

Over the total number of prey items recovered $(\mathrm{N}=1158), 12$ families contributed over $1 \%$ and together represented $90.5 \%$ of the consumed prey, with the other 30 invertebrate families making up only $9.5 \%$ of the ingested prey. Three invertebrate families added up to over $60 \%$ of the 
Table 1: Taxonomic composition of prey items $(\mathrm{N}=1158)$ found in stomachs $(\mathrm{N}=91)$ of Bufo spinosus. See text for variable explanation. Lv.: larvae.

\begin{tabular}{|c|c|c|c|c|c|}
\hline Class & Order & Family & $\mathrm{N} \%$ & $\mathbf{B} \%$ & $\mathbf{F} \%$ \\
\hline Oligochaeta & & & 2.85 & 0.01 & 20.88 \\
\hline Gastropoda & & & 0.09 & 0.05 & 1.10 \\
\hline \multirow[t]{6}{*}{ Arachnida } & Araneae & Dysderidae & 0.17 & 0.16 & 2.20 \\
\hline & & Gnaphosidae & 0.17 & 0.08 & 2.20 \\
\hline & & Lycosidae & 0.95 & 1.51 & 10.99 \\
\hline & & Not identified & 0.17 & 0.09 & 2.20 \\
\hline & Opiliones & Phalangiidae & 1.47 & 0.26 & 4.40 \\
\hline & Acari & Ixodoidea & 0.17 & 0.03 & 1.10 \\
\hline Crustacea & Isopoda & Oniscidea & 0.69 & 0.20 & 4.40 \\
\hline \multirow[t]{39}{*}{ Insecta } & Hymenoptera & Formicidae & 25.73 & 2.63 & 56.04 \\
\hline & & Vespidae & 0.17 & 0.14 & 2.20 \\
\hline & & Not identified & 0.09 & 0.03 & 1.10 \\
\hline & Orthoptera & Acrididae & 0.43 & 1.27 & 4.40 \\
\hline & Diptera & Muscidae & 0.17 & 0.03 & 2.20 \\
\hline & & Muscidae (lv.) & 0.43 & 0.06 & 1.10 \\
\hline & & Tipulidae (lv.) & 0.26 & 0.30 & 2.20 \\
\hline & & Not identified (lv.) & 0.26 & 0.11 & 2.20 \\
\hline & Hemiptera & Coreidae & 0.09 & 0.07 & 1.10 \\
\hline & & Pentatomidae & 0.69 & 0.24 & 7.69 \\
\hline & & Pyrrhocoridae & 0.09 & 0.02 & 1.10 \\
\hline & & Reduviidae & 0.26 & 0.09 & 3.30 \\
\hline & Lepidoptera & Noctuidae & 0.09 & 0.11 & 1.10 \\
\hline & & Not identified & 0.09 & 0.11 & 1.10 \\
\hline & & Geometridae (lv.) & 0.35 & 0.26 & 3.30 \\
\hline & & Lymantriidae (lv.) & 0.09 & 0.01 & 1.10 \\
\hline & & Noctuidae (lv.) & 0.09 & 0.06 & 1.10 \\
\hline & & Not identified (lv.) & 1.73 & 1.54 & 18.68 \\
\hline & Coleoptera & Carabidae & 9.93 & 8.23 & 46.15 \\
\hline & & Chrysomelidae & 2.94 & 3.65 & 19.78 \\
\hline & & Curculionidae & 1.04 & 0.45 & 8.79 \\
\hline & & Lagriidae & 0.09 & 0.04 & 1.10 \\
\hline & & Malachidae & 0.09 & 0.03 & 1.10 \\
\hline & & Cerambycidae & 0.17 & 2.17 & 1.10 \\
\hline & & Meloidae & 0.26 & 0.39 & 3.30 \\
\hline & & Scarabaeidae & 1.30 & 0.64 & 14.29 \\
\hline & & Staphylinidae & 4.06 & 7.50 & 25.27 \\
\hline & & Tenebrionidae & 6.30 & 5.52 & 26.37 \\
\hline & & Not identified & 0.86 & 0.17 & 6.59 \\
\hline & & Carabidae (lv.) & 1.04 & 0.36 & 6.59 \\
\hline & & Dermestidae (lv.) & 0.09 & 0.03 & 1.10 \\
\hline & & Lampyridae (lv.) & 0.69 & 0.34 & 7.69 \\
\hline & & Staphylinidae (lv.) & 0.78 & 0.31 & 6.59 \\
\hline & & Not identified (lv.) & 0.17 & 0.04 & 2.20 \\
\hline & Dermaptera & Forficulidae & 3.80 & 3.06 & 18.68 \\
\hline & Myriapoda & Geophilomorpha & 0.35 & 2.09 & 3.30 \\
\hline & & Julidae & 27.55 & 55.30 & 80.22 \\
\hline & & Lythobiomorpha & 0.43 & 0.08 & 4.40 \\
\hline & & Scolopendromorpha & 0.26 & 0.12 & 2.20 \\
\hline
\end{tabular}


prey: Julidae (27.55\%), Formicidae $(25.74 \%)$ and Carabidae (adults + larvae) (10.97\%).

Dry weight biomass estimates (B\%) of the invertebrate prey showed that only 12 families contributed with more than $1 \%$ to the total ingested biomass in our sample, but together represented $95 \%$ of the biomass. Interestingly, the 12 families contributing to ingested biomass at a higher degree are not the same 12 families mentioned in the previous paragraph as contributors for N\%. A total of $55 \%$ of the total biomass corresponded solely to Julidae, followed by Carabidae (8.6\%) and Staphilinidae (7.8\%). Although numerically (N\%) ants (Formicidae) constituted over $25 \%$ of the prey, they only represented $2.6 \%$ of the total ingested biomass (B\%).

The dry weights of the Julidae millipedes considered to estimate the biomass were calculated following HódAr (1996). Our empirical measurements on a subsample of this taxon $(\mathrm{N}=23)$, when extrapolated to an ideal cylinder (Margalef, 1983), consistently resulted in dry weight biomass values that were $20 \%$ lower than the estimates obtained following HóDAR (1996). Furthermore, the ash-free inorganic weight of a measured sub-subsample $(\mathrm{N}=$ 12) showed that $41.4 \%$ of the empirically measured dry weight of the Julidae millipedes is composed of ash-free inorganic matter.

The relative frequency of appearance $(\mathrm{F} \%)$ of the invertebrate prey in the stomachs of B. spinosus showed that 10 families of invertebrates appeared in more than $10 \%$ of the sampled toads, six families in more than $20 \%$ of the toads, and four families in more than $30 \%$ of the toads: Julidae
$(80.2 \%)$, Formicidae (56\%) Carabidae $(52.7 \%)$, and Staphilinidae $(31.9 \%)$, which reflects a rather varied diet.

Some invertebrate specimens were well preserved and could be identified to the species level. Most ants (Formicidae) seemed to belong to the species Camponotus pilicornis (minor) (Roger, 1859) and Messor bouvieri (Bondroit, 1918). Other identified species were Ocypus olens (Müller, 1764), Vesperus xatarti (Dufour, 1839) and Pyrrhocoris apterus (L., 1758).

We detected the presence of fecal pellets, probably belonging to lagomorphs, in five of the sampled stomachs. We also found undigested vegetal matter (mostly twigs and dry oak leafs) in 16 stomachs. The presence of vegetal matter in an empty stomach was found in a single case, and in another case the only other non-vegetal content was a single ant (Formicidae).

\section{Discussion}

Ants (Formicidae) and Coleoptera seem to be the prey items of greater importance in the diet of B. spinosus in our study area, based on $\mathrm{N} \%$ values. These results are in line with previous studies in B. bufo and B. spinosus (García-París, 1985; Cornish et al., 1995; Mollov et al., 2006; Dimancea \& Covaciu-Marcov, 2009; Mollov \& BoyadZhiev, 2009; Ortiz-SANTALiestra, 2014). However, despite their abundance as prey items in toad stomachs, ants only represent a minor fraction of the total ingested biomass (B\%), and thus their importance in terms of meeting the nutritional needs of $B$. spinosus appears to be secondary with respect to other prey like Coleoptera.

Millipedes (Julidae) also seem to have a significant importance in the diet of B. spi- 
nosus, based on our data. The particular nature of the Julidae family makes them an interesting case, since our results showed that the dry weight of these millipedes is made up by $41.40 \%$ of inorganic matter, which probably does not contribute in any way to meet the daily energetic requirements of the toads. Correcting for this amount of inorganic matter (by considering only $58.6 \%$ of the biomass of Julidae as actual biomass available for the toads), the contribution of Julidae towards the total consumed biomass (B\%) would be $42 \%$ instead $55.3 \%$, still by far the leading contributing family.

Another remarkable observation is the relatively high frequency of appearance (F\%) of Lampyridae (glow-worms) larvae in the stomachs of B. spinosus $(7.69 \%$ of the stomachs). This observation contrasts with previous studies, like De Cock \& Matthysen (2003), who argue strongly in favor of the unpalatability of glow-worms, and discuss the ability of toads to learn to avoid them, associating their potential toxicity with their specific luminescent aposematism.

Finally, we interpret the ingested vegetal matter as an accidental occurrence due to their diverse nature and their abundance in the areas where B. spinosus feed, but there seems to be a notable disparity of opinions in the consulted bibliography relative to the genus Bufo (SAMPEDroMARín et al., 2011). The interpretation of the fecal pellet ingestion by B. spinosus is more complicated, since the pellet diameters range from 10 to $15 \mathrm{~mm}$, which should make them perfectly distinguishable to $B$. spinosus. Sampedro-Marín et al. (2011) reported similar cases of coprophagia in

\section{Bufo marinus.}

\section{Conclusion}

Bufo spinosus from San Martín de la Vega in central Spain present a very rich diet (42 invertebrate families) when considering the entire sample, even though each individual toad only feeds upon a few different taxa per night and some families are rarely found. The most important invertebrate taxa in our study were Julidae millipedes, ants (Formicidae) and various families of coleopterans (Carabidae, Staphylinidae, Tenebrionidae). It is important to note that Formicidae contribute little to the total ingested biomass despite their high numerical presence. We hope that this descriptive study of the diet of $B$. spinosus will be useful for future research about the biology of this species and its conservation.

\section{Acknowledgement}

Ultimately, this study was possible thanks to the efforts of the existing group of environmental activists working on the M-301 road trying to minimize amphibian deaths during seasonal migrations. Our particular gratitude to the activist Mrs. Elena del Val del Olmo, who collected and preserved the studied specimens. Our acknowledgements as well to Jesús Herranz Barrera, who helped with the taxonomic identifications of invertebrates, and to Tania Trujillo Pereira-Santana, Íñigo Martínez-Solano, Enrique Ayllón López and Alberto Álvarez López, who are also studying and monitoring this amphibian population. Finally, sampling was done with the appropriate permissions granted by the Consejería de Medio Ambiente of 
Madrid (Ref. 10/480445.9/11). No mistreatment or harm was done to any living animal as all collected specimens were roadkilled individuals.

\section{REFERENCES}

Alonso-Zarazaga, M.Á. \& Mansilla CastriLlo, O. (1988). Clave Artificial de las Familias Ibero-Baleares y Macaronésicas del Orden Coleoptera L. 1758. Universidad Complutense, Madrid, Spain.

Arntzen, J.W.; McAtear, J.; Recuero, E.; ZiermanN, J.M.; Ohler, A.; van Alphen, J. \& Martínez-Solano, Í. (2013). Morphological and genetic differentiation of Bufo toads: two cryptic species in Western Europe (Anura, Bufonidae). Contributions to Zoology 82: 147-169.

BAs, S. (1982). La comunidad herpetológica de Caurel: biogeografía y ecología. AmphibiaReptilia 3: 1-26.

BeA, A.; Montori, A. \& Pascual, X. (1994). Herpetofauna dels Aiguamolls de l'Empordà, In J. Gosàlbez i Noguera, J. Serra i Raventós \& E. Velasco i Batlle (eds.) Els Sistemes Naturals dels Aiguamolls de l'Empordà. Series: Treballs de la Institució Catalana d'Història Natural, vol. 13. Institució Catalana d'Història Natural, Barcelona, Spain, pp. 359407.

Campeny, R. \& Montori, A. (1995). Feeding of an Iberian population of Bufo bufo during the reproductive period, In G.A. Llorente, A. Montori, X. Santos \& M.Á. Carretero (eds.) Scientia Herpetologica. Asociación Herpetológica Española, Barcelona, Spain, pp. 172-175.

Chinery, M. (1988). Guía de los Insectos de Europa. Omega, Barcelona, Spain.

Cornish, C.A.; Odham, R.S.; Bullock, D.J. \& Bullock, J.A. (1995). Comparison of the diet of adult toads (Bufo bufo L.) with pitfall trap catches. Herpetological Journal 5: 236238.

De Cock, R. \& Matthysen, E. (2003). Glow- worm larvae bioluminescence (Coleoptera: Lampyridae) operates as an aposematic signal upon toads (Bufo bufo). Behavioral Ecology 14: 103-108.

Díaz-Paniagua, C.; Gómez Rodríguez, C.; Portheault, A. \& De Vries, W. (2005). Los Anfibios de Doñana. Organismo Autónomo de Parques Nacionales, Madrid, Spain.

Dimancea, N. \& Covaciu-Marcov, S.D. (2009). The trophic spectrum of a Bufo bufo population (Amphibia) from Iezer Mountain, Argeş County, Romania. Universitatea Din Craiova University of Craiova 14: 469-474.

García-París, M. (1985). Los Anfibios de España. Ministerio de Agricultura, Pesca y Alimentación, Madrid, Spain.

Gittins, S.P.; Parker, A.G. \& Slater, F.M. (1980). Population characteristics of the common toad (Bufo bufo) visiting a breeding site in Mid-Wales. Journal of Animal Ecology 49: 161-173.

Glista, D.J.; DeVault, T.L. \& DeWoody, J.A. (2008). Vertebrate road mortality predominantly impacts amphibians. Herpetological Conservation and Biology 3: 77-87.

Gómez-Menor, J. (1956). Tribus de Hemípteros de España. Consejo Superior de Investigaciones Científicas, Madrid, Spain.

Harde, K.W. \& Severa, F. (1984). Guía de Campo de los Coleópteros de Europa. Omega, Barcelona, Spain.

HódAr, J.A. (1996). The use of regression equations for estimation of arthropod biomass in ecological studies. Acta Oecologica 17: 421433.

Jones, D. (1985). Guía de Campo de los Arácnidos de España y de Europa. Omega, Barcelona, Spain.

Kovar, R.; Brabec, M.; Bocek, R. \& Vita, R. (2009). Spring migration distances of some Central European amphibian species. Amphibia-Reptilia 30: 367-378.

Lizana, M. (1990). Ecología de Bufo bufo en la Sierra de Gredos. Ph.D. Dissertation, Universidad de Salamanca, Salamanca, Spain.

Lizana, M.; Ciudad, M.J. \& Pérez-Mellado, V. 
(1986). Uso de los recursos tróficos en una comunidad ibérica de anfibios. Revista Española de Herpetología 1: 207-271.

Margalef, R. (1983). Limnología. Omega, Barcelona, Spain.

Martínez, M.D.; Acosta, F.J. \& Ruiz, E. (1985). Claves para la Identificación de la Fauna Española: 12. Las Subfamilias y Géneros de Hormigas Ibéricas (Him. Formicidae). Cátedra de Entomología de la Facultad de Biología de la Universidad Complutense, Madrid, Spain.

Mollov, I. \& Boyadzhiev, P. (2009). A contribution to the knowledge of the trophic spectrum of the common toad (Bufo bufo L., 1758) (Amphibia: Anura) from Bulgaria. Zoonotes 4: 1-4.

Mollov, I.A.; Boyadzhiev, P.S. \& Donev, A.D. (2006). A synopsis of the studies on the trophic spectrum of the amphibians in Bulgaria. Animalia 41: 115-131.

Ortiz-Santaliestra, M.E. (2014). Sapo común Bufo spinosus, In A. Salvador, Í. MartínezSolano (eds.) Enciclopedia Virtual de los Vertebrados Españoles. Museo Nacional de Ciencias Naturales, Madrid, Spain. Available at http://www.vertebradosibericos.org/. Retrieved on 30 September 2017.

Ortuño Hernández, V.M. \& Toribio, M. (1996). Los Coleópteros Carábidos: Morfología, Biología y Sistemática. Fauna de la Comunidad de Madrid. Ministerio de Medio Ambiente, Organismo Autónomo Parques Nacionales, Madrid, Spain.

Paños, B.; Rubio, R. \& Barrios, F. (2009). Atropellos masivos de sapos en un carril bici. Quercus, 278: 4.
Quinney, T.E. \& Ankney, C.D. (1985). Prey size selection by tree swallows. The Auk 102: 245-250.

Sampedro-Marín, A.C.; Ángulo Villalba, Y.Y.; Arrieta Díaz, F.I. \& Dominguez AtenCiA, D.M. (2011). Alimentación de Bufo marinus (Linnaeus, 1758) (Bufonidae: Anura), en una localidad de Sucre, Colombia. Caldasia 33: 495-505.

Santos, X.; Llorente, G.A.; Montori, A.; CArretero, M.A.; Franch, M.; Garriga, N. \& Richter-Boix, A. (2007). Evaluating factors affecting amphibian mortality on roads: the case of the common toad Bufo bufo near a breeding place. Animal Biodiversity and Conservation 30: 97-104.

Sснмidt, B.R. \& Zumbach, S. 2008. Amphibian road mortality and how to prevent it: a review, In J.C. Mitchell, R.E. Jung Brown, \& B. Bartolomew (eds.) Urban Herpetology. Society for the Study of Amphibians and Reptiles, Saint Louis, Missouri, USA, pp. 157167.

Trujillo, T.; Gutiérrez-Rodríguez, J.; Arntzen, J.W. \& Martínez-Solano, Í. (2017). Morphological and molecular data to describe a hybrid population of the common toad (Bufo bufo) and the spined toad (Bufo spinosus) in western France. Contributions to Zoology 86: 1-10.

Vignes, J.C. (1998). Primeras observaciones sobre la alimentación de sapos (Bufo bufo) juveniles durante la emergencia en el País Vasco. Munibe Ciencias Naturales 50: 73-75.

Zahradnik, J. (1990). Guía de los Coleópteros de España y Europa. Omega, Barcelona, Spain. 